Article

\title{
Evaluation of the Policy of the Creative Industry for Urban Development
}

\author{
Yu-Yun Liu ${ }^{1}$ and Yin-Hao Chiu ${ }^{2, *}$ \\ 1 Institute of Educational Administration and Evaluation, University of Taipei, Taipei 10048, Taiwan; \\ giga1209@gmail.com \\ 2 Department of Urban Development, University of Taipei, Taipei 11153, Taiwan \\ * Correspondence: yhchiu@go.utaipei.edu.tw; Tel.: +886-02-2871-8288 (ext. 3102)
}

Academic Editors: Bon-Gang Hwang and Ming Shan

Received: 26 April 2017; Accepted: 2 June 2017; Published: 11 June 2017

\begin{abstract}
Culture, an intellectual capital of a city, is accumulated through the intellect and wisdom of the government, citizens, businesses and other organizations. Cities regardless of their size are seeking their own distinguishing features and positions. By combining culture and creativity to improve international visibility, cities can develop new potentials, create job opportunities and boost economic growth. Therefore, cultural and creative industries have become the core industries that cities worldwide actively seek to develop; furthermore, various city governments have unanimously agreed that the creative industry will effectively improve urban economic competitiveness. This study investigated how the creative industry improved urban competitiveness, developed relevant assessment indexes and formulated policies for developing the creative industry. First, the fuzzy Delphi method was adopted to determine the indexes for assessing the creative industry's positive influence on urban competitiveness. Subsequently, the analytic hierarchy process and the analytic network process were integrated to establish a model for assessing city-based creative industry development policies. City governments seeking to promote such policies can refer to this model. Finally, an importance-performance analysis was performed to investigate the satisfaction for policies related to creative industries, providing a reference for governments to promote pertinent policies. The results of this study indicated that the indexes of innovation capability, industrial cooperation, innovation incubation and industry-government-academia integration are crucial bases for cities to develop the creative industry. In addition, the policies of industrial R\&D and clustering, talent training and industrial consulting and expanding industrial and marketing channels and networks can be adopted to enhance creative industry development.
\end{abstract}

Keywords: creative industry; city competitiveness; fuzzy Delphi method (FDM); analytic network process (ANP); importance performance analysis (IPA); urban development strategy

\section{Introduction}

The concepts of cultural creativity and the creative economy have been increasingly valued globally. Countries worldwide have started to promote policies on cultural and creative industries (CCIs), rendering these industries the focus of industrial development in the respective countries. Furthermore, the annually increasing level of consumption in emerging countries has caused CCIs to raise global purchasing power. Creative industries, which emphasis creativity, facilitate the transformation of traditional industries and the development of newly emerging industries through soft power industries, such as culture and leisure, showcase a country's economic growth and have thus become a critical strategy for improving the core competitiveness of national economies. The country is composed of cities, while cities vary due to the geographic, social and science development. Thus, the cultures of cities may be different from each other. Art and culture are 
the essential foundations of the urban development, and the Untied Stated first applied them as a tool to enhance the city development, then followed by many European cities [1-3]. Therefore, the role of cultural and creative industries in the evolution of urban space is becoming increasingly important. Many world-class cities have become the central place for the cultural and creative industries and also attract funds, talent, as well as resources to create the industrial cluster. Cities such as Buenos Aires, Berlin, Vancouver, Seoul and Shanghai are named "Design Capitals" by the United Nations Educational, Scientific and Cultural Organization (UNESCO). These cities all commit to the development of culture and creative industries and also support their unique culture characteristics. The actions include the reconstruction of old cities and the planning and development of the new culture park. Design becomes the core direction of the industrial development in the 21st century because it provides a wide range of forms and applications to many fields and also has led the culture and creative industries to the new stage.

According to the analytical report released by PricewaterhouseCoopers on the global entertainment and media market, the overall scale of global creative industries (including advertising, television and digital media) was approximately US\$1.86 trillion (equivalent to approximately NT\$55.53 trillion) in 2014. The scale is estimated to reach US\$2.27 trillion (NT\$67.77 trillion) in 2018. These figures show that the growth and scale of creative industries are flourishing in the current volatile circumstances of global trade, thus encouraging countries and cities worldwide to invest more resources and formulate comprehensive policies to develop suitable creative industries. Hall $(1999,2000)$ indicated that CCIs will become the core activities of urban economic development in the future [4,5]. Culture is the accumulation of a country's art and life experiences. Combining culture with new creativity can create new development potential and business opportunities, generate job opportunities and facilitate economic growth for a country. Therefore, support for creative industries is necessary and crucial. This research is a cross-field study of urban development and creative industries. The research aim is to explore how the creative industries can enhance the competitiveness of the city by developing the assessment indicators and development strategy based on the creative industry of urban development. Taipei was selected as the World Design Capital (WDC) [6] in 2016, which may provide plenty of opportunities to show its innovation design among economic, social and cultural development to the world. WDC is a global event sponsored by International Council of Societies of Industrial Design (ICSID) [7] and is held every two years. Torino was chosen in 2008; Seoul was the next; and Helsinki was represented in 2012; and before Taipei was Cape Town. As a consequence, Taiwan is selected as a case study in the research and shares its experience with the neighboring countries as one of the developing countries. Firstly, the FDM is adapted to establish the evaluation index of the city competitiveness in the creative industry. Secondly, the AHP and ANP methods are combined to build up the selection mode. Lastly, IPA is applied in the study to carry out the satisfaction survey of the creative industry strategy and examine the expectation from both governments and experts of the industry. The research methods can be used as a mechanism for policy decision-making from the determination of critical development factors to the formulation of policy options and the inspection of the results.

The United Kingdom was the first country to propose the concept and policy of creative industries. Former Prime Minister Anthony Blair initiated this idea and established a Creative Industries Task Force in 1997, regarding creative industries as the major force and source of economic growth in the future. In the United Kingdom, creative industries are defined as 'those activities which have their origin in individual creativity, skill and talent and which have the potential for wealth and job creation through the generation and exploitation of intellectual property'. The release of the Creative Industries Mapping Documents 2001 raised the attention of countries worldwide to the creative industry, a long-existing industry that was yet to be valued and considered with specific policies. The term creative industry is defined differently among different countries, and its several variants include the creative industry (used in United Kingdom and Japan), cultural industry (used in the United Nations Educational, Scientific and Cultural Organization, France and China), cultural content industry (adopted in South Korea) and cultural and creative industry (used in Taiwan, Germany and Hong Kong). Nevertheless, the creative industry is increasingly listed as a key industry for 
development by countries worldwide [8]. The Executive Yuan of Taiwan proposed Challenge 2008: Six-Year National Development Plan, incorporating the Plan for Developing Cultural and Creative Industries, formulating policies for achieving the goal of 'industrialized culture and culturalized industry' and fully demonstrating the government's initiative in promoting CCIs. To facilitate CCI development, the government plans to enrich Taiwan's social environment both in terms of culture and creativity, employ technology and innovation research and development (R\&D) to improve talent training in these industries and actively develop domestic and international markets. In addition, the Law for the Development of the Cultural and Creative Industries was formulated and promulgated in 2010. It defines CCIs as 'industries that originate from creativity or accumulation of culture which through the formation and application of intellectual properties, possess potential capacities to create wealth and job opportunities, enhance the citizens' capacity for arts, and elevate the citizens' living environment'.

Domestic and international research on CCIs has mostly focused on CCIs' influence on urban and local development, elements for constructing CCI parks and strategies and suggestions for developing CCI clusters. This study mainly investigated CCIs and categorized and elaborated on them according to their content and objectives. Concerning CCIs' influence of urban and local development, several studies have indicated that cultural industries should enhance CCI development, establish high-tech platforms, develop promising corporate cultures, build a sound legal system, improve social security and advance competiveness through innovation, art and the process of collective learning [9-11]. Regarding the elements for establishing CCI parks, Chiu et al. (2012) [12] and Montgomery $(2003,2004)[13,14]$ have proposed and described the assessment models, requisites and developments of CCI development types. According to Chiu et al. (2012) [12], CCI types can be assessed using the following seven models: transportation, cultural resources, spatial cost, historical resources, industrial conditions, management and R\&D training resources. Montgomery $(2003,2004)[13,14]$ indicated that successful cultural zones should involve three dimensions, namely activity, form and meaning. In terms of the strategies and suggestions for developing CCI clusters, various studies have maintained that CCI clusters form through advantages in geographical location, the density of surrounding knowledge-related institutions, related industry chains and software and hardware facilities in the region, and cannot only enhance creative formation and product innovation, but also enable the continuous growth of innovative characteristics; furthermore, industry chains should be based on existing cultural environments and meanings while taking consumer products and services into consideration [15-18].

The daily output value of CCIs worldwide, calculated in 10 million U.S. dollars, grows by approximately $5 \%$ on average every year. In addition to their characteristics of high growth, high revenue and high added value, CCIs enable countries to create job opportunities, generate cultural and economic benefits and enhance citizen's cultural literacy, national image and national industry promotion to facilitate international tourism and trade. Therefore, many countries are actively promoting CCI policies and development. This study compiled the CCI policies of Taiwan, its neighboring countries in Asia and those of Western countries. Generally, these policies can be classified into eight categories: policies on tax systems, establishment of dedicated sectors or organizations, diverse capital investments, industrial $\mathrm{R} \& \mathrm{D}$ and consulting, expansion of marketing channels and networks, talent training and matchmaking, clustering of creative industries and intellectual property regulations. Table 1 shows the CCI-promoting policies and plans adopted by various countries. According to the table, these countries mostly employ tax incentives for CCI enterprises and direct financial or corporate capital into CCIs. Concurrently, governmental and nongovernmental organizations should collaborate in establishing mechanisms for investment, financing and credit guarantee, as well as creating foundations and projects. In addition, offices dedicated to CCIs should be established to serve as a platform for government: business stakeholder communication and coordination, provide consultation and support for industries and reinforce terms of use for intellectual property rights. Creative talent training programs should also be implemented to promote the introduction of CCI-related courses and knowledge into school education in order to incubate new talents and strengthen the public's cultural literacy. In addition to competence development, governments should actively expand market demand, ensuring effective local promotion 
and exchange networks in the domestic market while developing safeguard measures for exports in the international market [19].

Table 1. The categories of cultural and creative industry (CCIs)-promoting policies in Taiwan and other countries.

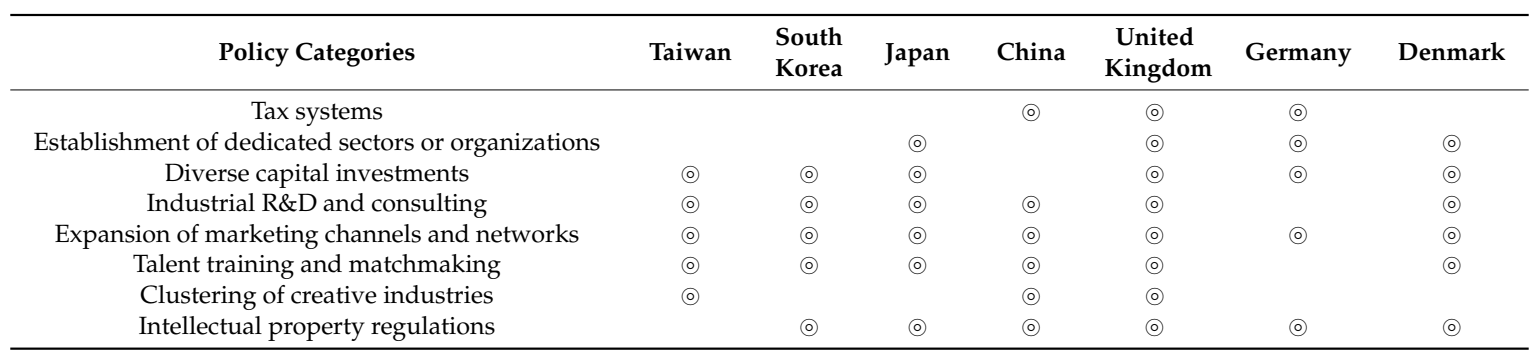

Note: $\odot$ it shows the policy projects that the countries are promoting.

\section{Research Methods}

The present study's primary concern is to assess and select CCI-oriented urban development indexes and policies for Taiwan's government to refer to when it formulates policies for promoting CCI-based urban development in the future. The framework of this study is mainly divided into three stages. First, this study referred to domestic and international theories and studies on various countries' CCIs and urban competitiveness indexes. Second, the fuzzy Delphi method (FDM) was employed, in which experts were invited to answer questionnaires for analyzing and selecting CCI development indexes. Third, this study summarized the CCI policies adopted by these countries and proposed five major strategies for developing CCIs. The analytic hierarchy process (AHP) and analytic network process (ANP) were adopted to rank the CCI-oriented urban development criteria and policies as a reference for governments to promote CCI strategies. Finally, an importance-performance analysis (IPA) was performed to determine if governments' awareness of CCI promotion policies corresponds with the observations made by CCI-related industrial, official and academic professionals. Research argues that the sample size and the selection of the experts are vital factors for the results. FDM is required to continue the communication through the experts to obtain the consensus of the issues. As a result, the selected members should be the experts of the subject areas to improve the validity of the study. Dalkey and Helmer (1963) [20] suggest that experts between 10 and 30 can most reduce the error value and obtain the highest reliability of the experiment. Delbecq et al. (1975) [21] argue that 10 to 15 members could achieve the need of the study if the background of the experts is homogeneous. In contrast, five to 10 experts could fulfil a study that involves various evaluations. In this research, eight experts, who are chosen from academics, public sectors, as well as the industry, are all involved in the creative industry. Three are three representatives of the governments: two are academics, and three are from the industry. Table 2 illustrates the background of the eight experts.

Table 2. Expert profile.

\begin{tabular}{lccc}
\hline & Organization & Position Seniority & Seniority \\
\hline 1 & Ministry of Finance & Deputy Minister & 33 \\
\hline 2 & Industrial Development Bureau, Ministry of Economic Affairs & Deputy Director & 15 \\
\hline 3 & Urban and Rural Development Department, New Taipei City & Deputy Commissioner & 21 \\
\hline 4 & Phototroph Engineering Consultants & Manager & 15 \\
\hline 5 & $\begin{array}{c}\text { Architecture, Engineering, Consulting, } \\
\text { Operations and Maintenance (AECOME) }\end{array}$ & $\begin{array}{c}\text { Vice president and Planning and Design } \\
\text { Director of Asia }\end{array}$ & 25 \\
\hline 6 & Culture and Creative Marketing Office, & Chief of Department & 15 \\
\hline 7 & Nation Palace Museum & Professor and the Dean & 24 \\
\hline 8 & University & Professor and the Head of the Department & 18 \\
\hline
\end{tabular}




\subsection{Fuzzy Delphi Method}

The Delphi method is a social science research method that involves inviting multiple anonymous experts to participate in several rounds of non-face-to-face questionnaire-based communication to make decisions, solve problems and forecast future events as a team. Rather than employ large sample sizes, the process of this questionnaire survey emphasizes the multiple rounds of discussion and communication among expert team members and the use of quantification and statistics to obtain consistent results from expert opinions. The method was developed to obtain consistent opinions from a group of experts through non-face-to-face interaction to improve the efficacy of group decision-makers (Murry and Hammons, 1995) [22]. Murray et al. (1985) [23] authored the first study to integrate fuzzy sets into the Delphi method. Ishikawa et al. (1993) [24] adopted the concepts of cumulative frequency distribution and fuzzy integral to integrate expert opinions into fuzzy numbers, and this process is named the FDM. Jeng (2001) [25] adopted bitriangular fuzzy arithmetic to integrate expert opinions, where the grey zone can test whether the expert opinions converge consistently or not (i.e., reach a consensus; Figure 1). Accordingly, this study employed the FDM proposed by Jeng (2001) [25] to analyze and select crucial indexes for CCI-oriented urban development.

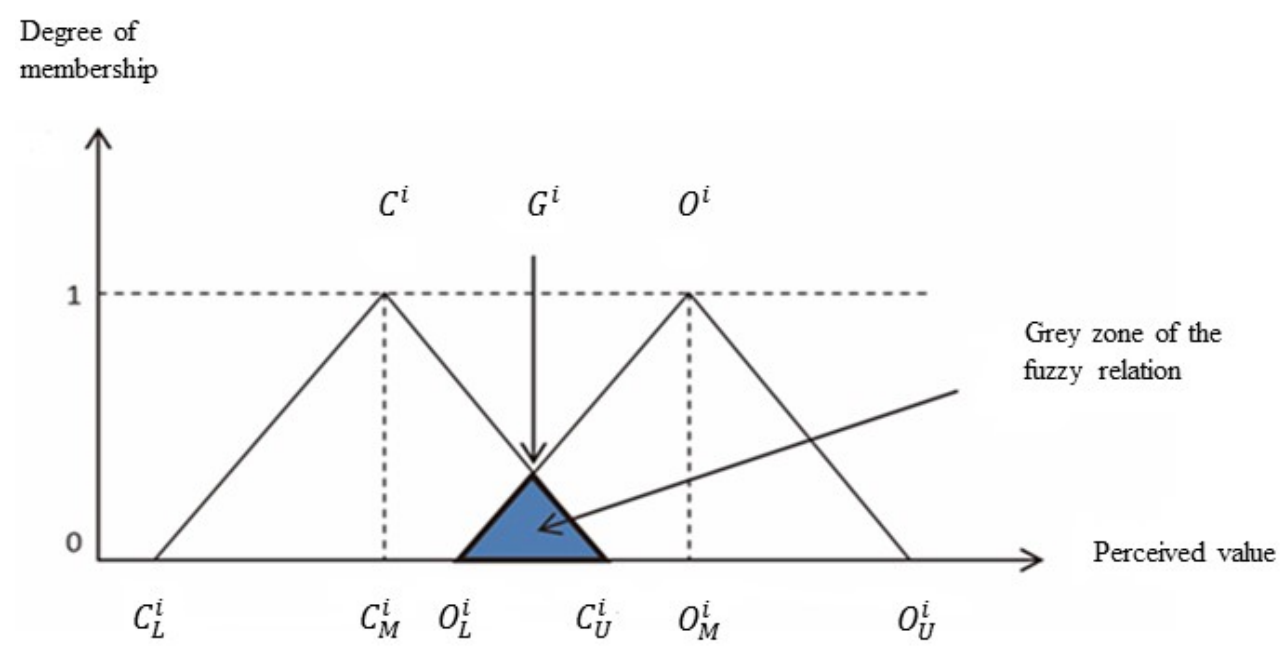

Figure 1. Diagram of the FDM proposed by Jeng (2001) [25].

\subsection{Analytic Network Process}

The ANP proposed by Saaty (1996) [26] is derived from the AHP. Saaty (1980) [27] indicated that although the AHP can facilitate the solving of problems involving multiple conditions and high levels of complexity, this method cannot take the interdependence among numerous conditions into account. Considering the interdependence and feedback among the various problems in reality, Saaty (2001) [28] to enhance the performance of this analytical instrument, extended the characteristics of the AHP to develop the theoretical model of ANP, in which elements at different levels are permitted to have complex interdependence.

In the ANP, elements and criteria at the same level exhibit mutual influence, and a feedback mechanism exists between each level. Therefore, the procedure is modified according to the characteristics of the ANP method by adding a super-matrix in the second phase when the weights of the elements at each level are calculated. A blank or zero in a super-matrix indicates that elements or clusters are mutually independent, and this mutual independence can be optimally used in assessing two types of interdependence (i.e., outer dependence and inner dependence). Outer dependence refers to mutual influence among clusters, whereas inner dependence denotes the correlation among elements in the same cluster. The values in each column of the super-matrix are stochastic, and the sum of all of the values in each column is one. After the super-matrix is weighted and its limit calculated, the interdependence among matrix elements will gradually converge, generating the relative weights 
of the elements. The ANP takes the interdependence among each criteria level and calculates the weights of elements from the mutual influence, as well as the feedback mechanism. Furthermore, the results can be revealed by the super-matrix that was composed of the comparison of the weight priority matrix. Thus, the ANP method is more suitable then the AHP method in this research to evaluate the policy separately and also to understand the differences and the interdependence between the criteria [29-31]. According to Weber (1990) [32], the characteristics of the mutual influence can be divided into three categories, which are the interdependence of technology, the interdependence of resources and interdependence of interests. Technical interdependence refers to the factors behind the success or failure of the mutual influence between a policy and another. Resources developed by one policy are used for another policy, and they share the benefits; this is called the interdependence of resources. As for the interdependence of interests, two interdependence policies may increase the expected utility, and the organization can be given a cost reduction or profit creation.

Cheng (2009) [33] indicates that the interdependence of ANP is closer to the human thinking mode; as a result, it may help the decision maker in most realistic situations. ANP can be applied to weight sorting, alternative product and program evaluation, strategic decision-making and risk assessment. Thus, its application can be very broad, such as education, architecture, finance, marketing, information management, industrial management, decision-making science and medical management. Sarkis et al. (2012) [34] proposed a model for assessing the sustainability of contractors by integrating the analytic hierarchy process and the analytic network process; Wey and Chiu (2103) [35] assessed the walkability of a pedestrian environment under the transit-oriented development; Hsu et al. (2007) [36] applied the analytic network process to the priorities of interdependent housing projects selection; Kao et al. (2017) [37] provided an evaluation study of the urban development strategy based on extreme climate conditions. Afterwards, the relative weights of feasible plans can be obtained to determine the optimal decision.

\subsection{Importance-Performance Analysis}

Martilla and James (1977) [38] indicated that IPA is an effective method for management teams to formulate marketing strategies and ascertain the effectiveness of marketing plans and consumer acceptance. According to Hollenhorst et al. (1992) [39], the overall means of importance and performance should be used as the points of division for two-dimensional IPA coordinate matrices to enhance the discriminative power of the distribution. Proposed by Martilla and James (1977) [38], the importance-performance analysis (IPA) technique provides a useful instrument for identifying the most crucial corporate attributes regarding their need for managerial action. It helps decision makers to set management priorities and determine how scarce resources might best be allocated. IPA is easy to apply in various contexts and provides the capacity to present strategic recommendations together with data [40]. As a result, IPA has been applied in various areas such as tourism [41]. The importance-performance analysis is applied to study the product attributes of the motorcycle industry and to help the industry to compare the strengths and the weakness. Moreover, IPA can analyze the results to improve the scheduling of the program and help the industry to improve its service, as well as customer satisfaction [42]. Chang et al (2017) [43] apply the importance-performance analysis (IPA) to analyze the transition pathways toward sustainability for construction enterprises. Liao and Lou (2013) [44] apply the analysis network process (ANP) and importance-performance analysis (IPA) to analyze the service quality and customer satisfaction of home-delivery service providers in the Taiwan market. IPA is also part of marketing research technology including the analysis of customer attitudes towards significant product or service attributes [45]. Furthermore, it applies in many markets, such as the automotive industry, catering industry, housing industry, education, healthcare, port analysis or the home furnishing industry [38,44,46-50].

This study adopted a modified IPA to assess CCI development policies. The means of the importance of and satisfaction for Taiwan's current CCI development policies were used to divide the two-dimensional matrix into four quadrants, as shown in Figure 2. Subsequently, the matrix was 
employed to analyze if the government's awareness of CCI promotion policies is consistent with the observations of CCI-related industrial, official and academic professionals. The results can serve as a reference for the government to implement policies and allocate resources. The definitions for the four quadrants are as follows:

- Quadrant 1 (A) refers to high importance and satisfaction, and items that fall within this quadrant represent aspects that are crucial and should be maintained (keep up the good work);

- Quadrant 2 (B) refers to low importance and high satisfaction, and items that fall within this quadrant represent aspects that have been overemphasized and should be given a lower priority in the future (possible overkill);

- Quadrant 3 (C) refers to low importance and satisfaction, and items that fall within this quadrant represent aspects that are not important (low priority);

- Quadrant 4 (D) refers to high importance, yet low satisfaction, and items that fall within this quadrant represent aspects that are highly relevant and should be improved with top priority (concentrate here).

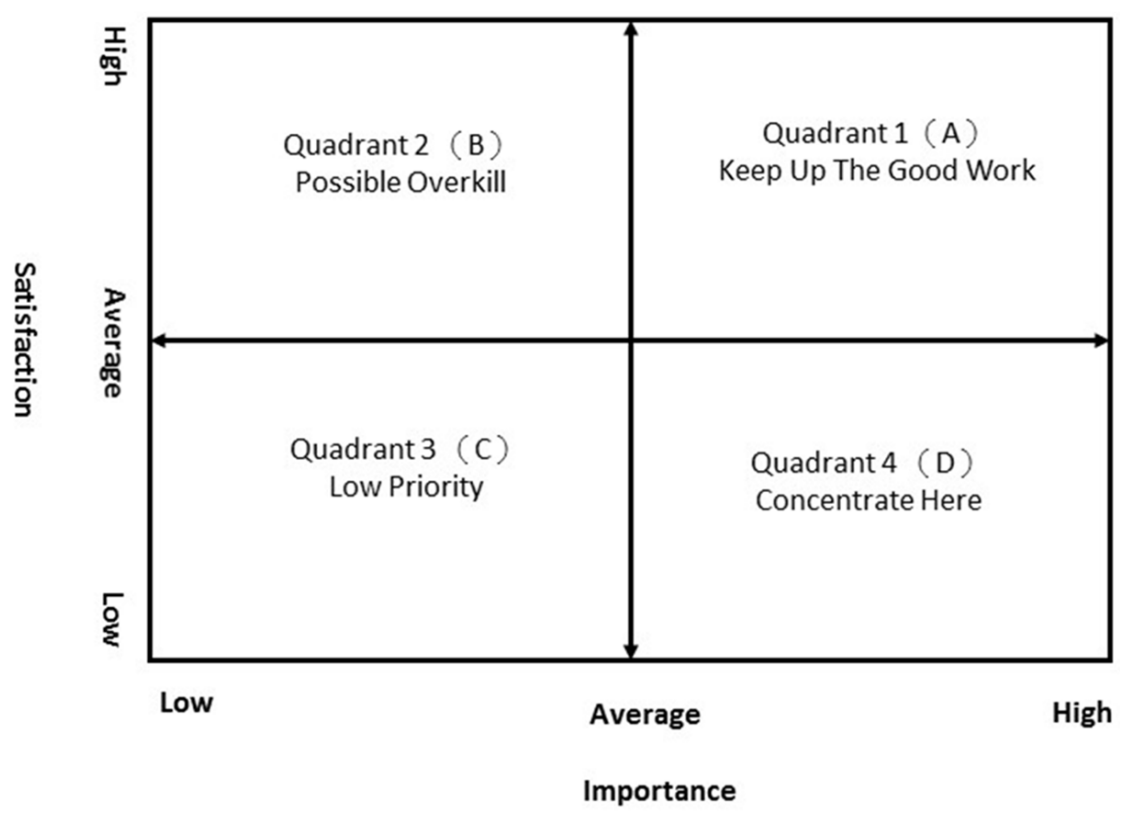

Figure 2. Two-dimensional IPA matrices (Martilla and James, 1977) [38].

\section{Establishing CCI-Oriented Urban Development Indexes}

\subsection{CCI-Oriented Urban Development Indexes}

Under globalization, cities have become the focus of economic, political and cultural development in various countries, which seek opportunities for increasing national or urban competitiveness and influence. In The Competitive Advantage of Nations, the author Michael E. Porter (1990) [51] proposed the Diamond model and indicated that national competitiveness denotes the level at which a country can create a favorable business environment for a specific industry of its own to gain competitive advantages in the international competition of that industry. Porter argued that productivity is the only purpose of competitiveness at the national level, and a country's fundamental objective is to provide its people with a high-quality life. This objective is attained through the productivity derived from national resources, such as labor and capital. The World Economic Forum defined the competitiveness of an economy as its ability to continuously maintain high economic growth on a sustainable basis. The International Institute for Management Development (IMD) [52] at Lausanne, Switzerland, defined national competitiveness as a country's ability in its economic and social structure 
to increase added value and thus national wealth by manipulating procedures that currently exhibit endowment effects and added value, demonstrating appeal to the domestic market and showing initiative to develop foreign markets, as well as internationalizing the domestic economy. According to the World Competitiveness Report, national competitiveness refers to a country's ability to create higher average personal wealth than the other competing countries in the global market; the Organisation of Economic Cooperation and Development regards national competitiveness as 'the degree to which a country can, under free and fair market conditions, produce goods and services which meet the test of the international market, while simultaneously maintaining and expanding the real incomes of its people over the longer term'. Ihlanfeldt (1995) [53] also mentions the significance of cities to the regional and national economic development; he hypothesizes that cities make an important contribution to regional and national economic growth that is attractive. Information exchange can occur more efficiently in dense urban environments, and there is evidence that the spatial concentration of economic activity is related to technological progress.

Currently, among representative studies on the concept of competitiveness, Kim (2000) [54] and Lever and Turok (1999) [55] have indicated the wide range of competitiveness at regional, national and international levels. In addition, Begg (1999) [56] and Kresl (1999) [57] have found the fundamental factors of competitiveness to comprise factors of production (i.e., natural resources, human resources and capital), the efficiency of factors of production in creating wealth (i.e., production technologies and management efficiency), actual wealth created annually (i.e., national income) and environment affecting the creation of national wealth (i.e., government efficacy, infrastructure, quality of life and economic liberalization). Kim (2000) [54] have also considered the contents of competitiveness to include factors such as products, services, social values, attitudes and education, arguing that competitiveness must be transformed in order to create new value, increase sustainability, produce high returns on production value and achieve a sustainable and high employment rate. In addition, the ultimate goal of improving competitiveness is to create the ability to increase average personal wealth, provide residents with welfare services and enhance their quality of life, as well as attain urban sustainable development. Kresl (1995) [58] proposed a formula for urban competitiveness as the function of economic and strategic determinants. Economic determinants include five categories, namely factors of production, infrastructure, location, economic structure and urban amenities; strategic determinants include the four categories of governmental effectiveness, urban strategy, public-private sector cooperation and institutional flexibility. Measuring competitiveness enables a country or industry to understand its own strengths and weaknesses and to focus on improving the weaknesses [59]. Currently, global rankings of urban competitiveness are compiled using urban competitiveness indexes developed according to the International Institute for Management Development (IMD) (Lausanne, Switzerland) [52], the World Economic Forum (Geneva), the 3Ts theory(Talent, Technology and Tolerance) from Europe in the Creative Age, the Report on the Global City Competitiveness Index (China) and the Asia-Pacific Cultural creative industry Association (2013) [60]. The dimensions of these indexes are compiled in Table 3. 
Table 3. Dimensions of the urban competitiveness index proposed by international institutes.

\begin{tabular}{|c|c|c|c|c|c|c|c|c|c|c|c|c|c|}
\hline $\begin{array}{l}\text { Index Dimension } \\
\text { Relevant Institute }\end{array}$ & $\begin{array}{c}\text { Economic } \\
\text { Performance }\end{array}$ & $\begin{array}{c}\text { Fiscal } \\
\text { Efficiency }\end{array}$ & $\begin{array}{l}\text { Industrial } \\
\text { Efficiency }\end{array}$ & Infrastructure & $\begin{array}{c}\text { Innovation } \\
\text { Management }\end{array}$ & $\begin{array}{c}\text { Talent } \\
\text { Training } \\
\end{array}$ & Technology & $\begin{array}{c}\text { Cultural } \\
\text { Tolerance }\end{array}$ & Openness & $\begin{array}{c}\text { Ecological } \\
\text { Environment }\end{array}$ & $\begin{array}{c}\text { Social } \\
\text { Welfare }\end{array}$ & $\begin{array}{c}\text { Social } \\
\text { Security }\end{array}$ & Health \\
\hline $\begin{array}{l}\text { International Institute } \\
\text { for Management } \\
\text { Development(IMD) [52], } \\
\text { Lausanne, Switzerland }\end{array}$ & ๑ & ๑ & ๑ & ๑) & & & & & & & & & \\
\hline World Economic Forum & ๑ & (॰) & (๑) & ( ) & ○ & & & & & & & & \\
\hline $\begin{array}{c}\text { Florida and Tinagli } \\
\text { (2004) [61], Europe in the } \\
\text { Creative Age }\end{array}$ & & & & & & ๑ & ๑) & ๑ & & & & & \\
\hline $\begin{array}{l}\text { Report on the Global City } \\
\text { Competitiveness Index }\end{array}$ & ๑ & & (๑) & ๑) & & & & & & & & & \\
\hline Commonwealth Magazine & ๑) & ๑) & & & & ๑) & & & & ๑) & ๑) & & \\
\hline Global View Monthly & (-) & & & & & ๑) & & ๑) & (-) & (-) & () & (อ) & ( ) \\
\hline $\begin{array}{l}\text { Asia-Pacific Cultural } \\
\text { Creative industry } \\
\text { Association (2013) [60] }\end{array}$ & ๑ & ๑) & ๑) & ๑) & ๑) & & & ๑) & & & & & \\
\hline
\end{tabular}

Note: $\odot$ it shows the policy projects that the countries are promoting. 


\subsection{Determining CCI-Oriented Urban Development Assessment Factors}

The fuzzy Delphi method was performed in two phases in this study. The first phase involved determining CCI-oriented urban development assessment factors; the second phase involved establishing the relative importance of assessment indexes. This study invited eight CCI-related industrial, official and academic experts to complete an expert questionnaire survey in each phase. In the first phase, CCI-oriented urban development assessment factors were determined. This study referred to CCI-related literature and urban competitive indexes both in Taiwan and other countries, and categorized considerations for CCI development into five dimensions, nine assessment items and 32 assessment factors. The five dimensions refers to the basic, fiscal, cultural and creative, industrial and social dimensions (respectively as Dimensions A, B, C, D and E). The basic dimension refers to the effect of a city's infrastructure, number of colleges and human resource development institutions on CCI development, and the indexes for this dimension consist of two items, namely infrastructure (denoted as A1) and education and training (A2). The fiscal dimension indicates the effects of a city's fiscal policies, laws and regulations and economic development on CCI development, and its indexes comprise two assessment items, namely policy support (B1) and fiscal situation (B2). The cultural and creative dimension refers to the effects of a city's cultural activities, preservation of historical monuments and innovation and R\&D capacity on CCI development, and its assessment items consist of cultural resources (C1) and creative potential (C2). The industrial dimension indicates the effects of a city's industrial conditions, proportion of industries and industrial exchanges on CCI development, and its assessment items are industrial development (D1) and industrial potential (D2). The social dimension denotes the effects of a city's social values and friendliness on CCI development, and its assessment item is social value (E1). The aforementioned assessment items are further divided into various assessment factors ranging from public transportation (A11), information and communication (A12), urban environment (A13), development space (A14), industry-government-academia integration (A21), human resources (A22) to social friendliness (E12). The definitions are presented in Table 4.

Table 4. Modified assessment factors for CCI-oriented urban development and their definitions.

\begin{tabular}{|c|c|c|c|}
\hline $\begin{array}{l}\text { First Level } \\
\text { (Assessment } \\
\text { Dimension) }\end{array}$ & $\begin{array}{c}\text { Second Level } \\
\text { (Assessment Item) }\end{array}$ & $\begin{array}{c}\text { Third Level } \\
\text { (Assessment Factor) }\end{array}$ & Definition of Assessment Factor \\
\hline \multirow{7}{*}{$\begin{array}{l}\text { A. } \\
\text { Basic } \\
\text { dimension }\end{array}$} & \multirow{4}{*}{$\begin{array}{c}\text { A1. } \\
\text { Infrastructure }\end{array}$} & $\begin{array}{c}\text { A11. } \\
\text { Public transportation }\end{array}$ & $\begin{array}{l}\text { Public urban transportation, including railways } \\
\text { (i.e., Taiwan Railways, Taiwan High Speed Rail, and metro systems), } \\
\text { highways (cars, buses, and long-distance buses), water transportation, } \\
\text { and aviation as well as their frequency of departure, passenger } \\
\text { volume, and the market share of public transportation. }\end{array}$ \\
\hline & & $\begin{array}{l}\text { A12. } \\
\text { Information and } \\
\text { communication }\end{array}$ & $\begin{array}{l}\text { Numbers and statistics of broadband users, internet users, mobile } \\
\text { phone users, landline subscribers, international calls, network } \\
\text { addresses issued, and domain name registrations. }\end{array}$ \\
\hline & & $\begin{array}{c}\text { A13. } \\
\text { Urban environment }\end{array}$ & $\begin{array}{l}\text { Urban public infrastructure's friendliness to residents and foreigners, } \\
\text { urban landscape planning, and their levels of influence on cities } \\
\text { seeking CCI development. }\end{array}$ \\
\hline & & $\begin{array}{c}\text { A14. } \\
\text { Development space }\end{array}$ & $\begin{array}{l}\text { Actual industrial space, virtual platforms, and } \\
\text { micro-entrepreneurship platforms for use. }\end{array}$ \\
\hline & \multirow{3}{*}{$\begin{array}{l}\mathrm{A} 2 . \\
\text { Education and } \\
\text { training }\end{array}$} & $\begin{array}{c}\text { A21. } \\
\text { Industry-government- } \\
\text { academia integration }\end{array}$ & $\begin{array}{l}\text { Numbers of universities and colleges, CCI-related institutes, research } \\
\text { institutes, and experts (including professors and doctoral graduates) } \\
\text { in a city. }\end{array}$ \\
\hline & & $\begin{array}{c}\text { A22. } \\
\text { Human resources }\end{array}$ & $\begin{array}{l}\text { Manpower invested by governmental sectors (including the Ministry } \\
\text { of Culture, Council for Cultural Affairs, and central and local } \\
\text { governments); numbers of civil servants, volunteers, and substitute } \\
\text { military service providers; and the proportions of R\&D personnel and } \\
\text { people with college education or higher. }\end{array}$ \\
\hline & & $\begin{array}{c}\text { A23. } \\
\text { Talent training }\end{array}$ & $\begin{array}{l}\text { Talent training invested by the government, schools, and society; } \\
\text { government scholarships for studying abroad; number of course } \\
\text { hours; numbers of foreign students and higher education teachers } \\
\text { and students; and the level of pervasiveness and influence of } \\
\text { aesthetic education in primary and secondary schools. }\end{array}$ \\
\hline
\end{tabular}


Table 4. Cont.

\begin{tabular}{|c|c|c|c|}
\hline $\begin{array}{l}\text { First Level } \\
\text { (Assessment } \\
\text { Dimension) }\end{array}$ & $\begin{array}{c}\text { Second Level } \\
\text { (Assessment Item) }\end{array}$ & $\begin{array}{l}\text { Third Level } \\
\text { (Assessment Factor) }\end{array}$ & Definition of Assessment Factor \\
\hline \multirow{7}{*}{$\begin{array}{l}\text { B. } \\
\text { Fiscal } \\
\text { dimension }\end{array}$} & \multirow{3}{*}{$\begin{array}{l}\text { B1. } \\
\text { Policy support }\end{array}$} & $\begin{array}{c}\text { B11. } \\
\text { Policies and regulations }\end{array}$ & $\begin{array}{l}\text { Number of culture-related regulations and policies added, amended, } \\
\text { and abolished. }\end{array}$ \\
\hline & & $\begin{array}{l}\text { B12. } \\
\text { Promotion/ } \\
\text { implementation }\end{array}$ & $\begin{array}{l}\text { Number of cultural activities and performances held by the } \\
\text { government and related sectors, annual rate of increase in the } \\
\text { activities held, number of attendants, and the annual rate of increase } \\
\text { in the number of attendants. }\end{array}$ \\
\hline & & $\begin{array}{l}\text { B13. } \\
\text { Financial support }\end{array}$ & $\begin{array}{l}\mathrm{CCI} \text { incentives and amounts of financial support, funds for corporate } \\
\text { financing, taxation of CCIs, and the intervention of business } \\
\text { angel funding. }\end{array}$ \\
\hline & \multirow{4}{*}{$\begin{array}{l}\text { B2. } \\
\text { Fiscal status }\end{array}$} & $\begin{array}{c}\text { B21. } \\
\text { Economic development }\end{array}$ & GDP, GDP per capita, fiscal revenue, and import and export value \\
\hline & & $\begin{array}{l}\text { B22. } \\
\begin{array}{l}\text { Amount of foreign direct } \\
\text { investment }\end{array}\end{array}$ & Local investment made by foreign corporations \\
\hline & & $\begin{array}{l}\text { B23. } \\
\text { Cultural expenditure }\end{array}$ & $\begin{array}{l}\text { The government's total budget for cultural expenditure, rate of } \\
\text { budget execution, and proportions of R\&D, educational, and } \\
\text { technological expenses in fiscal expenditure. }\end{array}$ \\
\hline & & $\begin{array}{c}\text { B24. } \\
\text { Social capital }\end{array}$ & $\begin{array}{l}\text { Number of social charitable donations and the government's } \\
\text { expenditure on social welfare. }\end{array}$ \\
\hline \multirow{9}{*}{$\begin{array}{l}\text { C. } \\
\text { Cultural and } \\
\text { creative } \\
\text { dimension }\end{array}$} & \multirow{6}{*}{$\begin{array}{l}\text { C1. } \\
\text { Cultural resources }\end{array}$} & $\begin{array}{c}\text { C11. } \\
\text { Traditional arts }\end{array}$ & $\begin{array}{l}\text { Numbers of traditional arts, folk art artefacts, registered antiquities } \\
\text { (e.g., copper and silverware, calligraphy and painting, historical } \\
\text { documents, and samples). }\end{array}$ \\
\hline & & $\begin{array}{l}\text { C12. } \\
\text { Cultural venues }\end{array}$ & $\begin{array}{l}\text { Numbers of museums, libraries, venues (for activities and } \\
\text { performances), and public art works. }\end{array}$ \\
\hline & & $\begin{array}{l}\text { C13. } \\
\text { Historical monuments }\end{array}$ & $\begin{array}{l}\text { Numbers of national or municipal historical monuments, buildings, } \\
\text { settlements, and archaeological sites. }\end{array}$ \\
\hline & & $\begin{array}{l}\text { C14. } \\
\text { Cultural landscape }\end{array}$ & $\begin{array}{l}\text { Number of cultural and natural landscapes (including national parks, } \\
\text { wildlife reserves, and state-owned forest preserves) in a city. }\end{array}$ \\
\hline & & $\begin{array}{c}\text { C15. } \\
\text { Cultural activeness }\end{array}$ & Cultural activities related to music or images. \\
\hline & & $\begin{array}{l}\text { C16. } \\
\text { Cultural consumption }\end{array}$ & $\begin{array}{l}\text { Numbers of subscriptions to newspapers, magazines, and } \\
\text { publications; number of new publications; and the circulation of } \\
\text { music and movies. }\end{array}$ \\
\hline & \multirow{3}{*}{$\begin{array}{l}\text { C2. } \\
\text { Creative potential }\end{array}$} & $\begin{array}{l}\text { C21. } \\
\text { City branding }\end{array}$ & $\begin{array}{l}\text { A city's frequency of marketing and exposure on websites, TV, } \\
\text { newspapers, and magazines; marketing consulting; and the } \\
\text { expansion of the market for product sales. }\end{array}$ \\
\hline & & $\begin{array}{l}\mathrm{C} 22 . \\
\text { Innovation incubation }\end{array}$ & $\begin{array}{l}\text { Numbers of CCI innovation incubation centers, firms having received } \\
\text { consulting services, and people employed after receiving consulting } \\
\text { services; the firms' output values; and the investment in } \\
\text { international personnel. }\end{array}$ \\
\hline & & $\begin{array}{l}\text { C23. } \\
\text { Innovation capability }\end{array}$ & $\begin{array}{l}\text { Number of people receiving the Wenxin Award, amount of } \\
\text { sponsorship, number of patent licenses and grants, ratio of corporate } \\
\text { R\&D investment, and number of patents per capita. }\end{array}$ \\
\hline \multirow{7}{*}{$\begin{array}{l}\text { D. } \\
\text { Industrial } \\
\text { dimension }\end{array}$} & \multirow{3}{*}{$\begin{array}{l}\text { D1. } \\
\text { Industrial } \\
\text { development }\end{array}$} & $\begin{array}{l}\text { D11. } \\
\text { Industrial clustering }\end{array}$ & $\begin{array}{l}\text { Numbers of CCI parks, activities, visits, and the evaluation of CCI } \\
\text { industry value chain. }\end{array}$ \\
\hline & & $\begin{array}{l}\text { D12. } \\
\text { Production value and } \\
\text { output }\end{array}$ & $\begin{array}{l}\text { Turnover of CCIs, proportion of CCI turnover to GDP, rate of increase } \\
\text { in turnover, output value of CCI firms, number of CCI firms, and rate of } \\
\text { increase in firm number, and revenue from domestic and export sales. }\end{array}$ \\
\hline & & $\begin{array}{c}\text { D13. } \\
\text { Labor market }\end{array}$ & $\begin{array}{l}\text { Number and growth rate of employees in culture-related industries; } \\
\text { ratio of these employees to those in the service industry. }\end{array}$ \\
\hline & \multirow{4}{*}{$\begin{array}{l}\mathrm{D} 2 . \\
\text { Industrial potential }\end{array}$} & $\begin{array}{l}\text { D21. } \\
\text { International exchange }\end{array}$ & $\begin{array}{l}\text { Number of times and participants of cultural activities or } \\
\text { performances held for international cultural exchange. }\end{array}$ \\
\hline & & $\begin{array}{l}\text { D22. } \\
\text { Number of tourists }\end{array}$ & $\begin{array}{l}\text { Number of tourists, tourist growth rate, ranking of tourist sites, } \\
\text { purposes of sightseeing, and tourism share in entire industries. }\end{array}$ \\
\hline & & $\begin{array}{l}\text { D23. } \\
\text { Industrial cooperation }\end{array}$ & $\begin{array}{l}\text { Number of CCI and cross-industry cooperation projects and the } \\
\text { number of platforms established. }\end{array}$ \\
\hline & & $\begin{array}{l}\text { D24. } \\
\text { International } \\
\text { organizations }\end{array}$ & $\begin{array}{l}\text { Numbers of international organizations that a city is a member of; } \\
\text { number of multinational headquarters of international agencies, } \\
\text { headquarters, and financial centers in a city. }\end{array}$ \\
\hline \multirow{2}{*}{$\begin{array}{c}\text { E. } \\
\text { Social } \\
\text { dimension }\end{array}$} & \multirow{2}{*}{$\begin{array}{c}\text { E1. } \\
\text { Social value }\end{array}$} & $\begin{array}{l}\text { E11. } \\
\text { Social diversity }\end{array}$ & $\begin{array}{l}\text { Level of tolerance for different ethnic groups and the number of } \\
\text { activities related to the gay cause. }\end{array}$ \\
\hline & & $\begin{array}{c}\text { E12. } \\
\text { Social friendliness }\end{array}$ & $\begin{array}{l}\text { Low crime rate, health care, and attitude towards foreign immigrants, } \\
\text { tourists, and visitors. }\end{array}$ \\
\hline
\end{tabular}




\subsection{Results of the FDM-Based Expert Questionnaire Survey}

In the second phase, eight experts who represent industry, government and academia respectively are invited in the research to contribute to the FDM-based expert questionnaires results. The second-phase FDM showed that the questionnaire scores did not generate values beyond twice the standard deviation, and all of the test values $\mathrm{Zi}$ of the indexes were greater than zero, indicating the convergence of assessment indexes and a high level of consistency in expert opinions. Several studies have suggested that FDM threshold values be set after the number of selected indexes is determined [62,63]. If the number of indexes is excessively small after selection, then the index values should be reduced. Conversely, although an excessively high threshold value can obtain the optimal judgment from experts, the number of assessment factors after selection will decrease, thus reducing the range of possible policies. Therefore, the geometric mean of consensus values is generally adopted as the threshold value, and factors passing the threshold value satisfy the standard of expert judgment. The selection results derived from FDM calculations are presented in Table 4, with 6.75 being the threshold value of expert consensus. According to the results of the second-phase FDM analysis, a total of nine factors exhibited an expert consensus value higher than the threshold value of 6.75. These factors were enumerated according to their expert consensus values from high to low as follows: innovation incubation, innovation capability, cultural venues, industrial cooperation, industry-government-academia integration, financial support, production value and output, international exchange and city branding. In other words, the experts reached consensus on the nine assessment factors and regarded them as more crucial than the other factors in assessing cities developing CCIs. Therefore, the nine assessment factors were included as crucial criteria affecting cities developing CCIs and used as the basis of assessment for the ANP method in the next phase of analysis. The assessment factors selected according to the FDM results are presented in Table 5.

Table 5. Second-phase statistical selection of criteria for assessing CCIs' influence on improving urban competitiveness.

\begin{tabular}{|c|c|c|c|c|c|c|c|c|c|c|c|}
\hline \multirow{2}{*}{ Assessment Factor } & \multicolumn{2}{|c|}{ Minimum Ci } & \multicolumn{2}{|c|}{ Maximum Oi } & \multicolumn{2}{|c|}{ Singular Value a } & \multicolumn{3}{|c|}{ Geometric Mean } & \multirow{2}{*}{ Test Value Zi } & \multirow{2}{*}{$\begin{array}{c}\text { Expert } \\
\text { Consensus } \\
\text { Value Gi }\end{array}$} \\
\hline & Min & Max & Min & Max & Min & Max & $\mathrm{Ci}$ & Oi & $\mathbf{A i}$ & & \\
\hline $\begin{array}{c}\text { A11. } \\
\text { Public transportation }\end{array}$ & 3.00 & 7.00 & 7.00 & 9.00 & 5.00 & 8.00 & 4.08 & 7.92 & 6.05 & 3.84 & $6.00 \leqq 6.75$ \\
\hline $\begin{array}{c}\text { A12. } \\
\text { Information and } \\
\text { communication }\end{array}$ & 4.00 & 6.00 & 7.00 & 8.10 & 5.00 & 7.00 & 4.79 & 7.88 & 6.25 & 4.09 & $6.33 \leqq 6.75$ \\
\hline $\begin{array}{c}\text { A14. } \\
\text { Development space }\end{array}$ & 3.00 & 6.00 & 6.00 & 9.00 & 5.00 & 7.00 & 4.65 & 7.59 & 6.20 & 2.94 & $6.12 \leqq 6.75$ \\
\hline $\begin{array}{c}\text { A21. } \\
\text { Industry-government- } \\
\text { academia integration }\end{array}$ & 5.00 & 6.00 & 7.00 & 9.00 & 6.00 & 7.00 & 5.52 & 8.41 & 6.74 & 3.89 & $6.96 \geqq 6.75$ \\
\hline $\begin{array}{c}\text { B11. } \\
\text { Policies and regulations }\end{array}$ & 3.00 & 5.00 & 6.00 & 8.00 & 5.00 & 7.00 & 4.17 & 7.40 & 5.97 & 4.23 & $5.79 \leqq 6.75$ \\
\hline $\begin{array}{c}\text { B12. } \\
\text { Promotion/ } \\
\text { implementation }\end{array}$ & 4.00 & 6.00 & 6.00 & 8.00 & 5.00 & 7.00 & 4.56 & 7.28 & 5.97 & 2.72 & $5.92 \leqq 6.75$ \\
\hline $\begin{array}{c}\text { B13. } \\
\text { Financial support }\end{array}$ & 5.00 & 6.00 & 7.00 & 9.00 & 6.00 & 7.00 & 5.27 & 8.42 & 6.71 & 4.15 & $6.85 \geqq 6.75$ \\
\hline $\begin{array}{c}\text { B21. } \\
\text { Economic development }\end{array}$ & 4.00 & 8.00 & 6.00 & 9.00 & 5.00 & 6.30 & 4.92 & 7.62 & 5.77 & 0.69 & $6.69 \leqq 6.75$ \\
\hline $\begin{array}{c}\text { B22. } \\
\begin{array}{c}\text { Amount of foreign direct } \\
\text { investment }\end{array}\end{array}$ & 2.00 & 3.00 & 5.00 & 7.00 & 4.00 & 5.00 & 2.57 & 6.03 & 4.39 & 5.46 & $4.30 \leqq 6.75$ \\
\hline
\end{tabular}


Table 5. Cont.

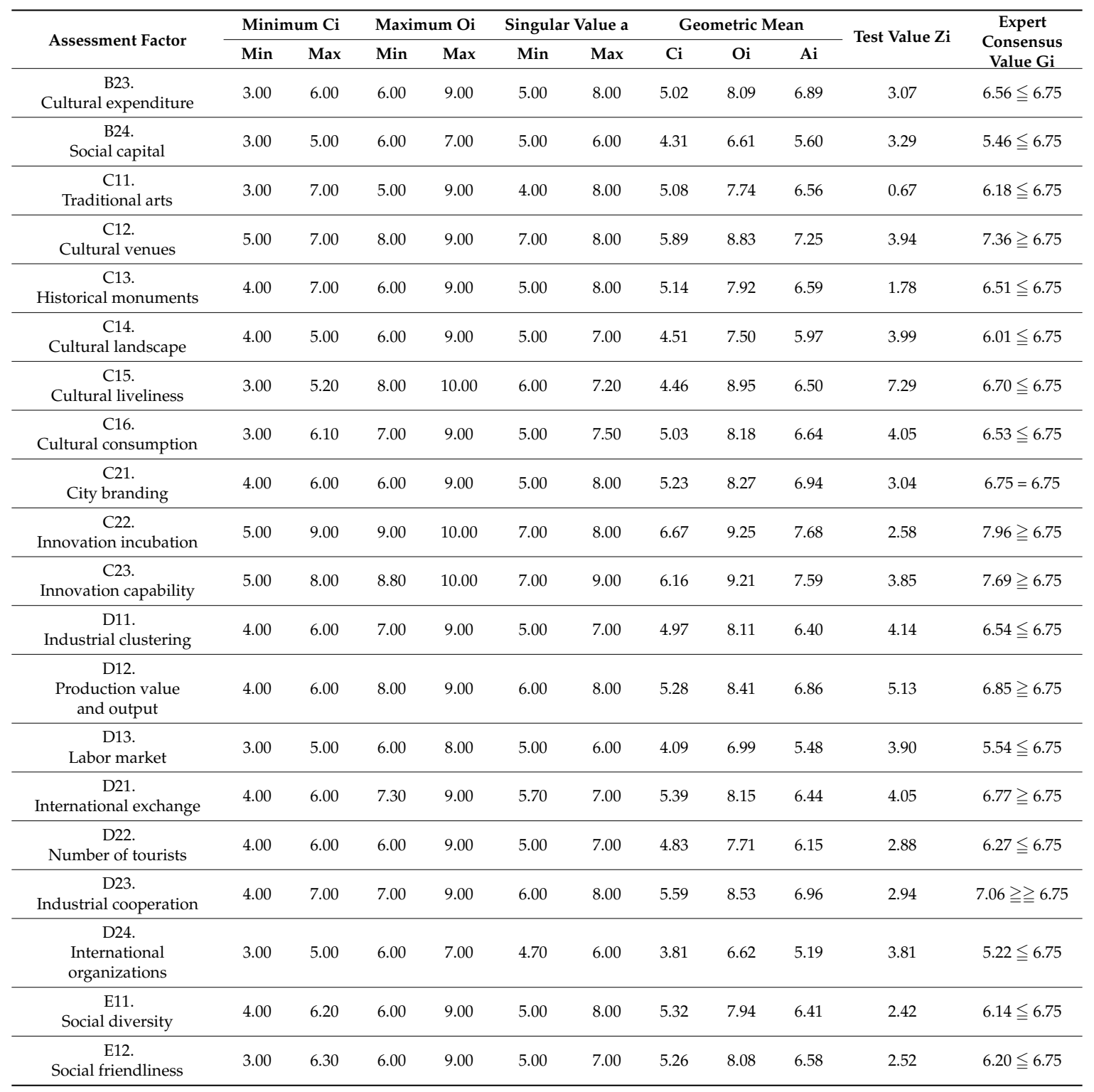

\subsection{Inner Dependence among the CCI Assessment Factors}

Before conducting paired comparisons on the retrieved questionnaires through the ANP, this study held an expert meeting to examine and determine whether inner dependence existed among the nine assessment factors that passed the threshold value. Subsequently, the ANP method was implemented to compare the priority weight of each development policy as the major reference for the empirical studies on CCI development policies. Figure 3 illustrates the inner dependence among all of the assessment factors. 


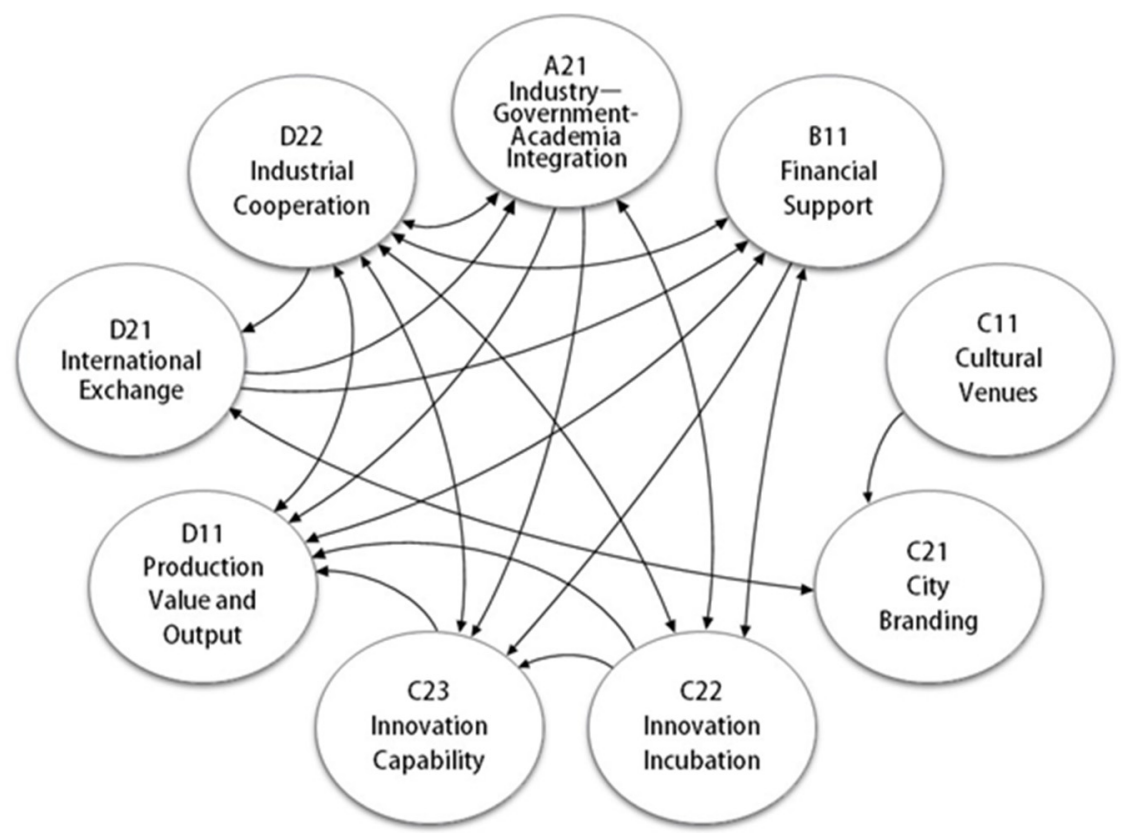

Figure 3. Inner dependence among all of the assessment factors.

\section{Developing CCI-Oriented Urban Development Policies}

\subsection{Policies for Cultural and Creative Industries}

According to the CCI policies promoted by governments worldwide in Section 2, this study proposed five CCI development policies as follows:

- Policy 1 (P1): Diversification of capital and tax systems:

The government should implement tax incentives for CCIs and introduce financial or corporate capital into these industries. Public and private sectors can collaborate in building mechanisms for investment, financing and credit guarantee, as well as creating foundations and projects. In addition, the government can provide preferential loans jointly with banks or offer funding programs to CCI small and medium-sized enterprises to boost CCI development.

- $\quad$ Policy 2 (P2): Industrial platforms and regulatory oversight:

CCI-dedicated departments or public service platforms can be established jointly by public and private sectors as a channel for industry-government communication and coordination to improve bilateral cooperation. Furthermore, CCI intellectual property should be protected and investigated, and the terms of use for intellectual property in online environments should be enhanced. Private sectors and the government should resist piracy and infringement together, as well as strengthen the inspection and ban on online infringement.

- $\quad$ Policy 3 (P3): Talent training and industrial consulting:

The government should propose CCI talent training programs or establish talent training institutes to nurture new talents. Concurrently, CCI knowledge should be introduced into education to enhance the public's CCI literacy. In addition, the government should provide industrial consulting, counselling and support regarding commercialization agreement on intellectual property, corporate operation of CCI firms, business matchmaking and the incubation or upgrade of competitive industries.

- Policy 4 (P4): Expansion of industrial and marketing channels and networks: 
The government should actively expand the domestic and international demands for CCIs. Effective local promotion and exchange networks should be maintained in the domestic market. Regarding the international market, in addition to developing safeguard measures for exports, the government should increase overseas business visits and exhibition participation, provide more business information for overseas markets through related organizations or export CCIs that have considerable potential.

- Policy 5 (P5): Industrial R\&D and clustering:

The government should assist CCIs in R\&D and transformation, as well as formulating an industry chain that links upstream and downstream CCI industries. In addition, the government should improve the management of CCI parks and CCI clusters, regard cultural facilities, such as museums and galleries, as crucial brands of CCIs, and implement effective branding to promote them.

The framework for assessing CCI-oriented urban development policies in this study is detailed in Figure 4.

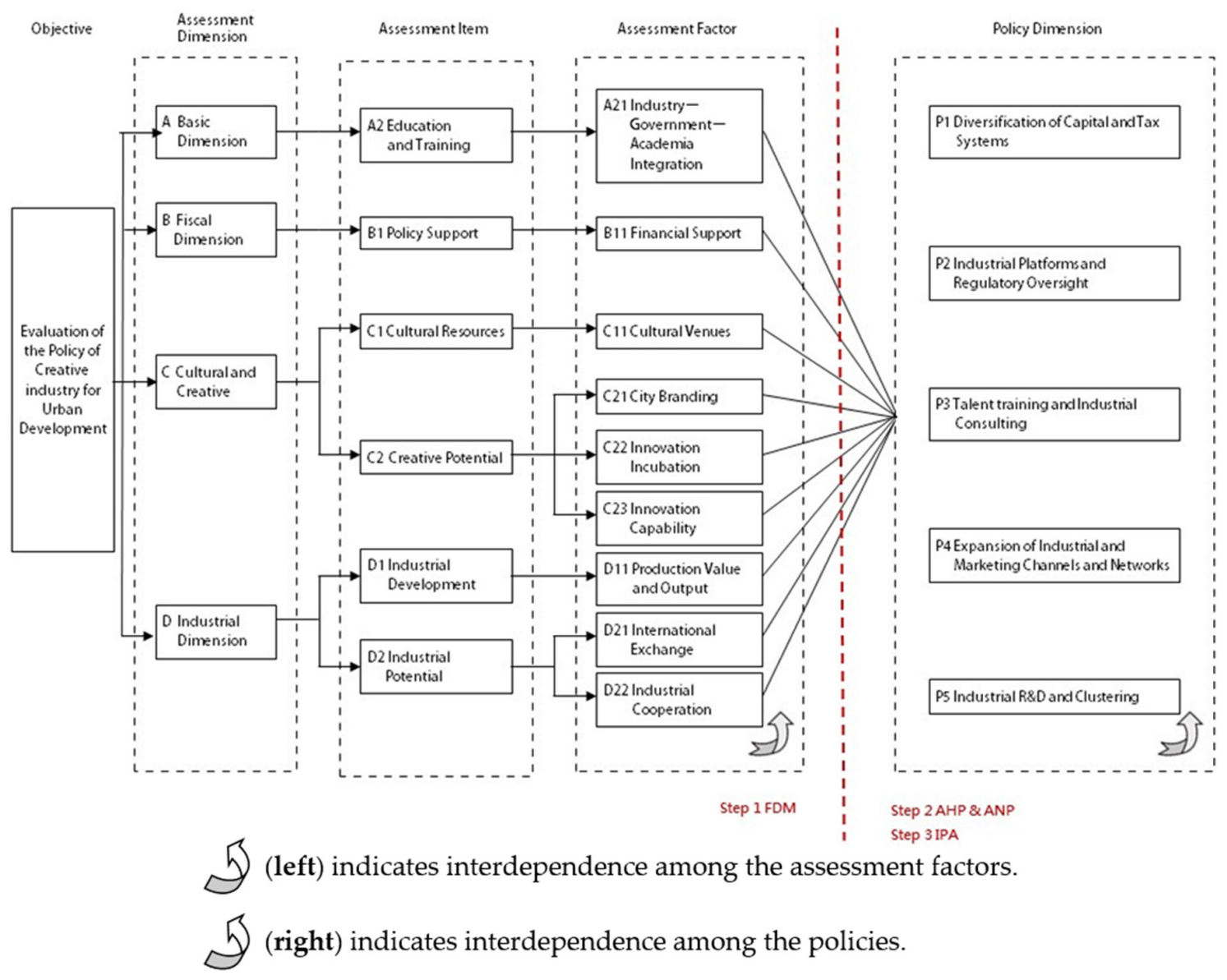

Figure 4. Framework for assessing CCI-oriented urban development policies.

\subsection{Analyzing the Results of the ANP-Based Expert Questionnaire Survey}

This study used the ANP to assess the opinions of eight experts specializing in CCI-related teaching and research. Questionnaires and statistical methods were used to obtain the experts' opinions about CCI development policies, and all of the distributed questionnaires were retrieved. The ANP method proposed by Saaty (1996) [26] was performed to assess the retrieved questionnaires. After the selection process, the different CCI development indexes were ranked according to their descending relative importance $\left(\mathrm{W}_{1}\right)$ as follows: $\mathrm{C} 23$ innovation capability $>$ D22 industrial cooperation $>\mathrm{C} 22$ 
innovation incubation $>$ A21 industry-government-academia integration $>$ D11 production value and output $>$ B11 financial support $>$ C21 city branding $>$ C11 cultural venues $>$ D21 international exchange. Among these indexes, C23 was the most crucial index with an overall weight percentage of $32.3 \%$, indicating that innovation capability exerts the greatest influence on CCI development in a city, followed by industrial cooperation. Considering the mutual influence among the indexes, the various $\mathrm{CCI}$ development indexes were ranked according to their relative importance $\left(\mathrm{W}_{\mathrm{C}}\right)$ as follows: C22 > D22 > D21 > B11 > A21 > D11 > C23 > C11 > C21. Among these indexes, C22, D22 and D21 were relatively crucial, the weight percentages of which were $19.9 \%, 17.1 \%$ and $16.7 \%$, respectively. In other words, given the mutual influence among the indexes, innovation incubation, industrial cooperation and international exchange are the main factors that affect a city's CCI development. The weight percentages of all of the indexes are compiled in Table 6. Indexes with a higher weight exerted a higher level of influence on the assessment and selection of CCI development policies for a city.

Table 6. Importance ranking of CCI development indexes.

\begin{tabular}{|c|c|c|c|c|c|c|}
\hline \multirow{2}{*}{$\begin{array}{l}\text { Importance } \\
\text { Ranking }\end{array}$} & \multicolumn{3}{|c|}{ Weights of CCI Development Indexes $\left(W_{1}\right)$} & \multicolumn{3}{|c|}{ Weights of CCI Development Indexes $\left(W_{C}\right)$} \\
\hline & Factor & Weight & $\%$ & Factor & Weight & $\%$ \\
\hline 1 & $\begin{array}{c}\text { C23. } \\
\text { Innovation capability }\end{array}$ & 0.322837 & $32.3 \%$ & $\begin{array}{c}\mathrm{C} 22 . \\
\text { Innovation incubation }\end{array}$ & 0.199192 & $19.9 \%$ \\
\hline 2 & $\begin{array}{c}\text { D22. } \\
\text { Industrial cooperation }\end{array}$ & 0.167318 & $16.7 \%$ & $\begin{array}{c}\text { D22. } \\
\text { Industrial cooperation }\end{array}$ & 0.171393 & $17.1 \%$ \\
\hline 3 & $\begin{array}{c}\mathrm{C} 22 . \\
\text { Innovation incubation }\end{array}$ & 0.145427 & $14.5 \%$ & $\begin{array}{c}\text { D21. } \\
\text { International exchange }\end{array}$ & 0.166731 & $16.7 \%$ \\
\hline 4 & $\begin{array}{c}\text { A21. } \\
\text { Industry-government- } \\
\text { academia integration }\end{array}$ & 0.108111 & $10.8 \%$ & $\begin{array}{l}\text { B11. } \\
\text { Financial support }\end{array}$ & 0.128662 & $12.9 \%$ \\
\hline 5 & $\begin{array}{c}\text { D11. } \\
\text { Production value and } \\
\text { output }\end{array}$ & 0.083879 & $8.4 \%$ & $\begin{array}{c}\text { A21. } \\
\text { Industry-government- } \\
\text { academia integration }\end{array}$ & 0.102618 & $10.3 \%$ \\
\hline 6 & $\begin{array}{c}\text { B1. } \\
\text { Financial support }\end{array}$ & 0.063624 & $6.4 \%$ & $\begin{array}{c}\text { D11. } \\
\text { Production value and } \\
\text { output }\end{array}$ & 0.102243 & $10.2 \%$ \\
\hline 7 & $\begin{array}{c}\text { C21. } \\
\text { City branding }\end{array}$ & 0.045035 & $4.5 \%$ & $\begin{array}{c}\text { C23. } \\
\text { Innovation capability }\end{array}$ & 0.048136 & $4.8 \%$ \\
\hline 8 & $\begin{array}{l}\text { C11. } \\
\text { Cultural venues }\end{array}$ & 0.034997 & $3.5 \%$ & $\begin{array}{l}\text { C11. } \\
\text { Cultural venues }\end{array}$ & 0.044187 & $4.4 \%$ \\
\hline 9 & $\begin{array}{c}\text { D21. } \\
\text { International exchange }\end{array}$ & 0.028771 & $2.9 \%$ & $\begin{array}{c}\text { C21. } \\
\text { City branding }\end{array}$ & 0.036838 & $3.7 \%$ \\
\hline
\end{tabular}

This study performed the traditional AHP and the ANP for comparison. When the mutual influence among CCI development indexes was not considered, the CCI development policies were ranked according to their relative importance $\left(\mathrm{W}^{A H P}\right)$ as follows: $\mathrm{P} 5$ industrial R\&D and clustering > P3 talent training and industrial consulting $>$ P4 expansion of industrial and marketing channels and networks $>$ P1 diversification of capital and tax systems $>$ P2 dedicated services and oversight units, among which, P5 was the most important (weight percentage $=25.9 \%$ ), followed by P3 $(23.9 \%$ ) and P4 (21.9\%). When the mutual influence among CCI development indexes was considered, the CCI development policies were ranked according to their descending relative importance $\left(\mathrm{W}^{A N P}\right)$ as follows: P5 > P4 > P3 > P1 > P2, among which, P5 was the most crucial (weight percentage $=26.6 \%$ ), followed by P4 (24.2\%) and P3 (22.8\%). The results yielded using the AHP and ANP showed little difference, indicating that the experts prioritized the policy of industrial R\&D and clustering before that of industrial and marketing channels and networks and that of talent training and industrial consulting. The importance rankings of the CCI development policies are compiled in Table 7. 
Table 7. Relative importance of CCI development policies determined according to CCI development indexes.

\begin{tabular}{|c|c|c|c|c|c|c|}
\hline \multirow{2}{*}{$\begin{array}{l}\text { Importance } \\
\text { Ranking }\end{array}$} & \multicolumn{3}{|c|}{ Weights of CCI Development Policies $\left(\mathrm{W}^{A H P}\right)$} & \multicolumn{3}{|c|}{ Weights of CCI Development Policies $\left(\mathrm{W}^{A N P}\right)$} \\
\hline & Policy & Weight & $\%$ & Policy & Weight & $\%$ \\
\hline 1 & $\begin{array}{c}\mathrm{P} 5 . \\
\begin{array}{c}\text { Industrial } \mathrm{R} \& \mathrm{D} \text { and } \\
\text { clustering }\end{array}\end{array}$ & 0.25887 & $25.9 \%$ & $\begin{array}{c}\mathrm{P} 5 . \\
\begin{array}{c}\text { Industrial } \mathrm{R} \& \mathrm{D} \text { and } \\
\text { clustering }\end{array}\end{array}$ & 0.26594 & $26.6 \%$ \\
\hline 2 & $\begin{array}{c}\text { P3. } \\
\text { Talent training and } \\
\text { industrial consulting }\end{array}$ & 0.23934 & $23.9 \%$ & $\begin{array}{c}\text { P4. } \\
\text { Expansion of industrial and } \\
\text { marketing channels } \\
\text { and networks }\end{array}$ & 0.24154 & $24.2 \%$ \\
\hline 3 & $\begin{array}{c}\text { P4. } \\
\text { Expansion of industrial and } \\
\text { marketing channels } \\
\text { and networks }\end{array}$ & 0.21872 & $21.9 \%$ & $\begin{array}{c}\text { P3. } \\
\text { Talent training and } \\
\text { industrial consulting }\end{array}$ & 0.22842 & $22.8 \%$ \\
\hline 4 & $\begin{array}{c}\text { P1. } \\
\begin{array}{c}\text { Diversification of capital } \\
\text { and tax systems }\end{array}\end{array}$ & 0.15381 & $15.4 \%$ & $\begin{array}{c}\text { P1. } \\
\begin{array}{c}\text { Diversification of capital } \\
\text { and tax systems }\end{array}\end{array}$ & 0.14654 & $14.7 \%$ \\
\hline 5 & $\begin{array}{c}\text { P2. } \\
\text { Dedicated services and } \\
\text { oversight units }\end{array}$ & 0.12927 & $12.9 \%$ & $\begin{array}{c}\text { P2. } \\
\text { Dedicated services and } \\
\text { oversight units }\end{array}$ & 0.11757 & $11.8 \%$ \\
\hline
\end{tabular}

\subsection{Analyzing the Importance of and Satisfaction for CCI-Oriented Urban Development Policies}

This study adopted the IPA modified by Hollenhorst et al. (1992) [39] and invited eight experts from CCI-related teaching and research fields to survey their perceived importance of and satisfaction for the five CCI development policies. The analysis showed that industrial, official and academic professionals' perceived levels of importance of CCI policies ranged from 4.13 to 4.46 (mean score $=4.31$ ), indicating the high importance of the five policies. The five policies in descending order of their importance scores were P1, P3, P5, P2 and P4. This order revealed that industrial, official and academic professionals were most concerned about the problems of capital and tax systems among all CCI policies. In contrast, the policy on expanding industrial and marketing channels and networks was not highly rated for importance probably because firms in Taiwan have mostly sought overseas market opportunities through other channels or by themselves rather than through the government. The industrial, official and academic experts' perceived levels of satisfaction for CCI policies ranged from 2.5 to 3.26 (mean score $=2.76$ ), showing that the experts held moderate attitudes towards the five policies. The five policies in descending order of their satisfaction scores were P3, P1, P4, P5 and P2. This order indicated that the experts were highly satisfied with talent training and industrial consulting among all CCI policies because Taiwan boasts transparent information and diverse channels for higher education and further studies that fulfils the needs of industrial talents to improve their skills and knowledge. However, the experts were lowly satisfied with dedicated services and oversight units probably because CCIs are being overseen according to their type by an excessively diverse number of competent authorities under the Ministries of Economic Affairs, Culture and Interior Affairs, and industries lack a specific governmental contact to consult when solving problems. Figure 5 shows that both the government and experts consistently perceived P3 as the current government's competitive advantage that should be maintained. By contrast, P5 and P1 were perceived differently between the government and experts. CCI policies in this quadrant are those that the government should actively prioritize for improvement to enhance urban competitiveness. P2 and P4 were policies that, although not prioritized, required improvement. Nevertheless, urban competitiveness would be consolidated, as well, if these policies are improved. 


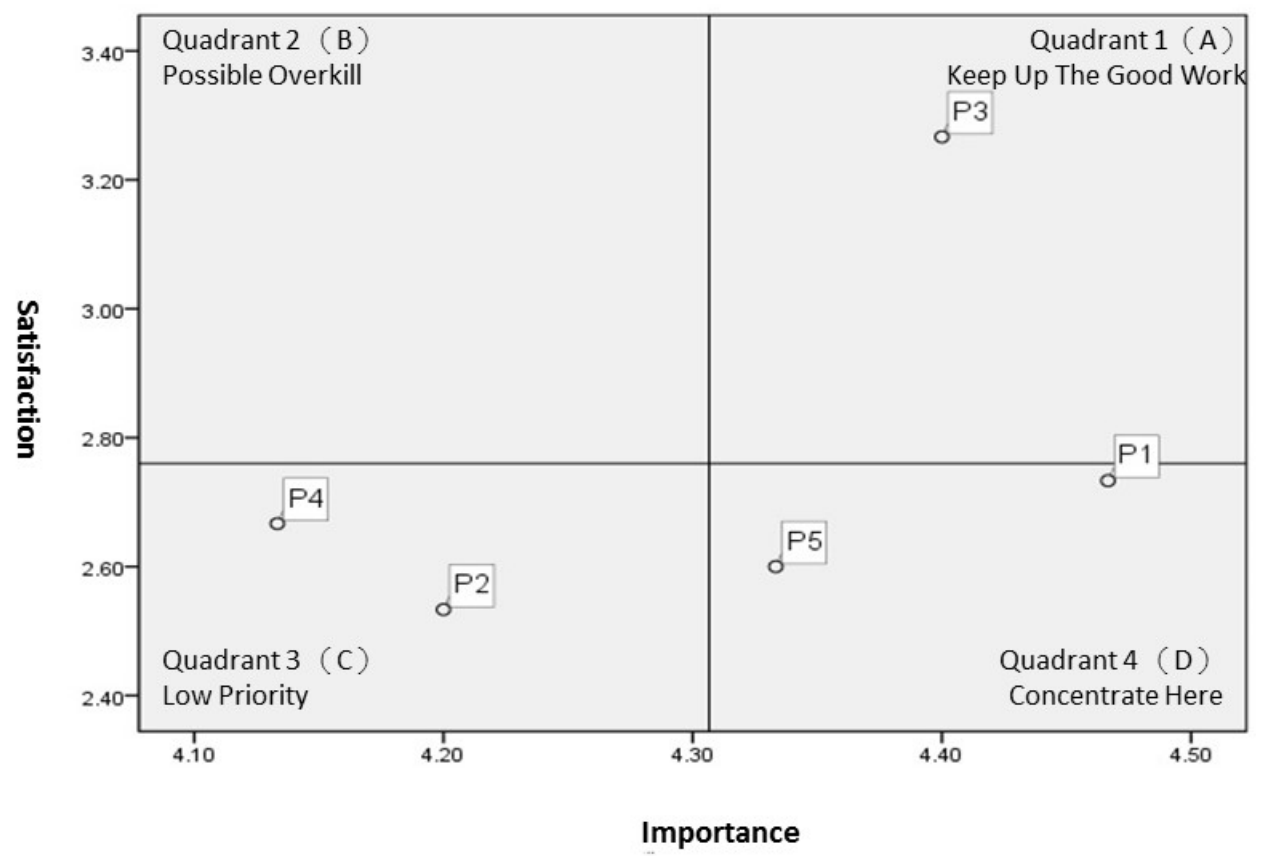

Figure 5. Analysis of CCI policy satisfaction and importance.

\section{Conclusions}

Currently, CCIs are the industries that countries and cities worldwide have sought to develop because they not only generate actual economic benefits, but also enhance urban competitiveness. When countries are unanimously committed to developing CCIs, their governments play a particularly crucial role in determining directions and policies for promoting CCI development. This study investigated CCIs' effect in improving urban competitiveness, developed related assessment indexes and formulated policies for developing CCIs. Initially, the FDM was implemented to identify the indexes for assessing CCIs' influence on enhancing urban competitiveness. Subsequently, the AHP and the ANP were integrated to establish a model for assessing and selecting policies for developing CCIs in cities. In addition, IPA was performed to investigate the importance of and satisfaction for the selected CCI policies. Governments can refer to these results when formulating policies for CCI development in cities. The findings of this study are summarized as follows:

\subsection{Establishing Indexes for Assessing Cultural and Creative Industry-Oriented Urban Development}

Under the assessment framework that CCIs can enhance urban competitiveness, this study compiled urban competitiveness indexes from domestic and international research to formulate indexes for assessing CCI development. After employing the FDM to analyze the questionnaires completed by experts, this study determined that nine indexes achieving consistent expert consensus can be ranked according to their decreasing expert consensus values as follows: innovation incubation, innovation capability, cultural venues, industrial cooperation, industry-government-academia integration, financial support, production value and output, international exchange and city branding. The consistent expert consensus on these indexes indicated that they are crucial bases for cities to develop CCIs. Furthermore, the aforementioned nine indexes were compared and analyzed in terms of their relative importance and mutual influence, and they were ranked according to their decreasing importance as follows: innovation capability, industrial cooperation, innovation incubation and industry-government-academia integration. Among these indexes, the mutual influence between innovation capability, industrial cooperation, innovation incubation and industry-government-academia integration was relatively strong. 


\subsection{Formulating Policies for Cultural and Creative Industries}

This study generalized five major policies for CCI development from the CCI policies promoted by various countries. Initially, the traditional AHP and the ANP were conducted to perform matrix operations on the questionnaires answered by the experts. The weights for the policies yielded when the inner dependence among the CCI development indexes was considered were compared with those obtained when the inner dependence was not considered. Subsequently, several CCI development policies were prioritized according to the resultant weights. When the inner dependence among CCI development indexes was not considered, the policies were ranked according to their weights (from high to low) as follows: industrial R\&D and clustering, talent training and industrial consulting, expansion of industrial and marketing channels and networks, diversification of capital and tax systems and dedicated services and oversight units. When the inner dependence among the CCI development indexes was considered, the policies were ranked according to their weights (from high to low) as follows: industrial R\&D and clustering, expansion of industrial and marketing channels and networks, talent training and industrial consulting, diversification of capital and tax systems and dedicated services and oversight units. Regardless of the method employed (i.e., the AHP or the ANP), the policy of industrial R\&D and clustering exhibited the greatest importance, achieving a weight percentage of over $25.9 \%$ (Table 6). This result indicated that the government should prioritize industrial R\&D and clustering for cities developing CCIs to enhance urban competitiveness. Therefore, the government should assist CCIs in R\&D and transformation, as well as formulating an industry chain that links upstream and downstream CCI industries. In addition, the government should improve the management of CCI parks and CCI clusters, regard cultural facilities, such as museums and galleries, as crucial brands of CCIs and implement effective branding to promote them. The tpolicy of talent training and industrial consulting and that of expanding industrial and marketing channels and networks were ranked the second and the third as crucial development policies, with a weight percentage of $23.9 \%$ and $21.9 \%$ (Table 6), respectively. In other words, the government should introduce CCI knowledge in schools to improve the public's CCI literacy, as well as provide industrial consulting, counselling and support regarding commercialization agreement on intellectual property, corporate operation of CCI industries, business matchmaking and the incubation or upgrade of competitive industries. Concurrently, the government should actively expand domestic and international demands for CCIs by maintaining effective local promotion and exchange networks in the domestic market and developing safeguard measures for exports in the international market to enhance the circulation of CCIs. In addition, the government should increase overseas business visits and exhibition participation, provide more business information for overseas markets through related organizations or export CCIs that have great potential. These results correspond with the CCI development policies implemented by various countries worldwide.

\subsection{Investigating the Satisfaction for and Importance of CCI Policies}

Finally, after performing IPA, this study found that the industrial, official and academic experts were most concerned about the diversification of capital and tax systems, followed by talent training and industrial consulting, industrial R\&D and clustering, dedicated services and oversight units and the expansion of industrial and marketing channels and networks. Moreover, the CCI policy with which experts were most satisfied was talent training and industrial consulting, followed by the diversification of capital and tax systems, expansion of industrial and marketing channels and networks, industrial R\&D and clustering and dedicated services and oversight units. Particularly, the policy of talent training and industrial consulting was considered highly important and satisfactory; therefore, this policy should be maintained. By contrast, the policy of industrial R\&D and clustering and that of the diversification of capital and tax systems were considered highly important yet lowly satisfactory; thus, the two policies should be prioritized for improvement to strengthen urban competitiveness. The policy of dedicated services and oversight units and that of the expansion of 
industrial and marketing channels and networks were considered lowly important and satisfactory; therefore, although they require improvement, they need not be prioritized.

This study employed the FDM to select the CCI development policies to be evaluated. Subsequently, the traditional AHP and the ANP were performed to calculate the ranking of priority weights among the policies. By doing so, this study established a model for assessing CCI-oriented urban development policies, and this model can serve as an objective and reliable method for governmental decision-makers to refer to when promoting CCIs. In addition, the results are consistent with that observed in actual industrial transformation, upgrade and CCI development undertaken by countries worldwide, while providing policies that concurrently improve urban industrial development and urban competitiveness. Therefore, the results of this study can serve as a reference for relevant research and countries formulating CCI development policies. After comparing and analyzing the results of this study and the CCI policies and projects currently implemented in Taiwan, this study proposed the following four suggestions and directions for improvement:

(1) Although the policy of talent training and industrial consulting is perceived as more satisfactory than other policies in Taiwan, dedicated services and oversight units should be incorporated to facilitate CCI firms' understanding of CCI-related laws and regulations and provide professional consultation services on business management. In addition, the government should focus on talent training and matchmaking services, enhance international talent training plans, develop vocational benchmarks for industrial professionals, design vocation courses and formulate CCI incubation support programs. In the future, CCI training should be divided into professional and in-service education. Professional education refers to secondary to university education, where vocational, skill-oriented courses should also be planned to develop talents. The in-service education that students attend after they join the labor force focuses on improving their expertise in response to industrial changes. Moreover, the government should suggest colleges to collaborate with firms in establishing specialized vocational schools while encouraging firms to help develop specialized talents to close the education-to-employment gap arising from the failure of educational and training institutions to provide the vocational skills demanded by the industries. Accordingly, colleges should introduce models of vocational training to enhance training efficacy while actively developing internationally-acknowledged vocational training courses to meet international standards and improve the industry's competitiveness in the international market.

(2) Regarding the diversification of capital and tax systems, CCI firms currently have access only to projects concerning investment, financing and capital market entry promoted by the Ministry of Culture for supporting industrial development. The government should provide CCI firms with diverse channels to learn from and seek available support that suits their needs by offering information about creative consultation resources, funding plans and R\&D via the promotion service network for Taiwan Cultural Creative Industries. In the future, the government should propose $R \& D$ and innovation plans or cross-industry $R \& D$ programs for each industry while assisting existing or start-up industries to undertake collaborative development, technological observation and learning, interdisciplinary integration or value-added applications to create new industrial value and competitiveness.

(3) To capitalize on the value chain integration and industrial competitive advantage induced by industrial clustering, the Ministry of Culture is currently implementing the project of building five CCI parks across Taiwan (in Taipei, Taichung, Hualien, Chiayi and Tainan) and an industrial clustering management plan. By commissioning private institutions and by issuing calls for tenders, the government expects these projects to create more business clusters, including crucial areas surrounding museums, art museums, science parks or industrial parks and, thus, enable industries and talents to interconnect and enhance the overall economic development of the hosting cities. 
(4) Regarding the policy of expanding industrial and marketing channels and networks, this study suggested that the government undertake international CCI expansion projects to organize CCI firms to attend international exhibitions, assist the firms to acquire orders and letters of intent, launch international cultural and creative industry-organization bridging plans and invite international buyers to visit the Creative Expo Taiwan and business matchmaking events in Taiwan while gathering various cultural brands at the events to facilitate matchmaking. In addition, the government should provide CCI firms with business information of overseas markets, ensure the implementation of various preferential policies for foreign CCI trade and support CCI firms to undertake market development activities, such as bidding, investment, exhibition, marketing and promotion in foreign countries.

Acknowledgments: This study is part of the project, an investigation into the policy of city development based on the cultural creative industry (Project No. MOST 105-2410-H-845-011-MY3), supported by the Ministry of Science and Technology, the Executive Yuan. We appreciate the Ministry of Science and Technology for the research funding.

Author Contributions: The individual contribution and responsibilities of the authors were as follows: Yin-Hao Chiu: Research idea and method design, grant holder of research financing, article writing, supervision of the research direction. Yu-Yun Liu: research idea, literature review, research data collection and analysis, article writing.

Conflicts of Interest: The authors declare no conflict of interest.

\section{References}

1. Whitt, J.A. Mozart in the metropolis: The arts coalition and the urban growth machine. Urban Aff. Q. 1987, 23, 15-36. [CrossRef]

2. Lister, D. The Transformation of a City: Birmingham. In Whose Cities? Fisher, M., Owen, U., Eds.; Penguin: Harmondsworth, UK, 1991.

3. Booth, P.; Boyle, R. See Glasgow, see culture. In Cultural Policy and Urban Regeneration-The West European Experience; Bianchini, F., Parkinson, M., Eds.; Manchester University: Manchester, UK, 1993.

4. Hall, P. The future of cities. Comput. Environ. Urban Syst. 1999, 23, 173-185. [CrossRef]

5. Hall, P. Creative cities and economic development. Urban Stud. 2000, 37, 639-649. [CrossRef]

6. World Design Capital. Available online: http://wdo.org/ (accessed on 26 December 2016).

7. Creative Cities Network. Available online: http://en.unesco.org/creative-cities/home (accessed on 26 December 2016).

8. Ministry of Culture. White Paper on Cultural Affairs; Ministry of Culture: Taipei, Taiwan, 2004.

9. Gregory, J.J. Creative industries and urban regeneration-The Maboneng precinct, Johannesburg. Local Econ. 2016, 31, 158-171. [CrossRef]

10. Cong, S.G.; Li, Y.P. The Study about Development Status, Trends and Paths of Cultural Industry in China. Energy Procedia 2011, 5, 2078-2081.

11. Ku, Y.L. Learning Town of the Cultural Industries in Taiwan. City Plan. 2007, 34, 75-94.

12. Chiu, Y.H.; Jheng, Y.M.; Hsieh, T.Y. Using Fuzzy Delphi Method and Analytic Network Process in the Development Assessment of the Cultural and Creative Industries Park. J. Archit. 2012, 80, 85-109.

13. Montgomery, J. Cultural quarters as mechanisms for urban regeneration. Part 1: Conceptualising cultural quarters. Plan. Pract. Res. 2003, 18, 293-306. [CrossRef]

14. Montgomery, J. Cultural quarters as mechanisms for urban regeneration. Part 2: A review of four cultural quarters in the UK, Ireland and Australia. Plan. Pract. Res. 2004, 19, 3-31. [CrossRef]

15. Zheng, J.; Chan, R. The impact of 'creative industry clusters' on cultural and creative industry development in Shanghai. City Cult. Soc. 2014, 5, 9-22. [CrossRef]

16. Evans, G. Creative cities, creative spaces and urban policy. Urban Stud. 2009, 46, 1003-1040. [CrossRef]

17. Ching, C.H. The Clustering of Creative Industries in Inner City of Taipei. City Plan. 2007, 34, 343-361.

18. Bassett, K.; Griffiths, R.; Smith, I. Cultural industries, cultural clusters and the city: The example of natural history film-Making in Bristol. Geoforum. 2002, 33, 165-177. [CrossRef]

19. The Danish Government. Denmark at Work, Plan for Growth in the Creative Industries Design. LIWEF, The Global Competitiveness Report 2013-2014. Klaus Schwab, World Economic Forum. 2013. 
Available online: http://em.dk/english/publications/2013/13-02-07-plan-for-growth-in-the-creativeindustries-and-design (accessed on 5 June 2017).

20. Dalkey, N.C.; Helmer, O. An experimental application of the Delphi method to the user of experts. Manag. Sci. 1963, 9, 458-467. [CrossRef]

21. Delbecq, A.L.; van de Ven, A.H.; Gustafson, D.H. Group Techniques for Program Planning: A Guide to Nominal Group and Delphi Processes; Scott, Foresman and Company: Glenview, IL, USA, 1975.

22. Murry, J.W.; Hammons, J.O. Delphi: A versatile methodology for conducting qualitative research. Rev. High. Educ. 1995, 18, 423-436. [CrossRef]

23. Murray, T.J.; Pipino, L.L.; Gigch, J.P. A pilot study of fuzzy set modification of Delphi. Hum. Syst. Manag. 1985, 5, 76-80.

24. Ishikawa, A.; Amagasa, T.; Tamizawa, G.; Totsuta, R.; Mieno, H. The Max-Min Delphi Method and Fuzzy Delphi Method Via Fuzzy Integration. Fuzzy Sets Syst. 1993, 55, 241-253. [CrossRef]

25. Jeng, T.B. Fuzzy Assessment Model for Maturity of Software Organization in Improving its Staff's Capability. Master's Thesis, Graduate Institute of Information Management, National Taiwan University of Science and Technology, Taipei, Taiwan, 2001.

26. Saaty, T.L. The Analytic Network Process; RWS Publications: Pittsburgh, PA, USA, 1996.

27. Saaty, T.L. The Analytic Hierarchy Process; McGraw-Hill, Inc.: Boston, MA, USA, 1980.

28. Saaty, T.L. Decision Making with Dependence and Feedback: The Analytic Network Process, 2nd ed.; RWS Publications: Pittsburgh, PA, USA, 2001.

29. Meade, L.M.; Sarkis, J. Strategic analysis of logistics and supply chain management systems using the analytic network process. Logist. Transp. Rev. 1998, 34, 201-215. [CrossRef]

30. Wey, W.M.; Chang, W.C. A Study on Selecting Optimal Product Design Solution Using Fuzzy Delphi Method and Analytic. J. Des. 2005, 10, 59-80.

31. Lee, J.W.; Kim, S.H. An integrated approach for independent information system project selection. Int. J. Proj. Manag. 2001, 19, 111-118. [CrossRef]

32. Weber, R.; Werners, B.; Zimmermann, H. Planning Models for Research and Development. Eur. J. Oper. Res. 1990, 48, 175-188. [CrossRef]

33. Cheng, Y.H. Theory and Application of the Analytic Network Process. J. Natl. Def. Manag. 2009, 30, 69-79.

34. Sarkis, J.; Meade, L.M.; Presley, A.R. Incorporating sustainability into contractor evaluation and team formation in the built environment. J. Clean. Prod. 2012, 31, 40-53. [CrossRef]

35. Wey, W.M.; Chiu, Y.H. Assessing the walkability of pedestrian environment under the transit-oriented development. Habitat Int. 2013, 38, 106-118. [CrossRef]

36. Hsu, H.M.; Wey, W.M.; Tsai, P.J. The Applications of Analytic Network Process to the Priorities of Interdependent Housing Projects Selection. J. Archit. 2007, 62, 49-74.

37. Kao, L.S.; Chiu, Y.H.; Tsai, C.Y. An Evaluation Study of Urban Development Strategy Based on of Extreme Climate Conditions. Sustainability 2017, 9, 284. [CrossRef]

38. Martilla, J.A.; James, J.C. Importance-performance analysis. J. Mark. 1977, 41, 77-79. [CrossRef]

39. Hollenhorst, S.; Olson, D.; Fortney, R. Use of importance-performance analysis to evaluate state park cabins: The case of the West Virginia State park system. J. Park Recreat. Adm. 1992, 10, 1-11.

40. Lai, L.S.; To, W. Importance-performance analysis for public management decision making: An empirical study of China's Macao special administrative region. Manag. Decision 2010, 48, 277-295. [CrossRef]

41. Pan, F.C. Practical application of importance-performance analysis in determining critical job satisfaction factors of a tourist hotel. Tour. Manag. 2015, 46, 84-91. [CrossRef]

42. Matzler, K.F.; Bailom, H.H.; Hinterhuber, B.R.; Pichler, J. The Asymmetric Relationship between Attribute-Level Performance and Overall Customer Satisfaction: A Reconsideration of the Importance-Performance Analysis. Ind. Mark. Manag. 2004, 33, 271-277. [CrossRef]

43. Chang, R.D.; Zuo, J.; Soebarto, V.; Zhao, Z.Y.; Zillante, G.; Gan, X.L. Discovering the Transition Pathways toward Sustainability for Construction Enterprises: Importance-Performance Analysis. J. Constr. Eng. Manag. 2017, 143, 04017013. [CrossRef]

44. Liao, T.Y.; Lou, Y.C. Service Quality and Customer Satisfaction for Home-delivery Service Providers-Case Study of Five Providers in Taiwan. J. E-Bus. 2013, 15, 461-490.

45. Hawes, J.M.; Rao, C.P. Using importance-performance analysis to develop health care marketing strategies. J. Health Care Mark. 1985, 5, 19-25. [PubMed] 
46. Cunningham, M.A.; Gaeth, G.J. Using importance-performance analysis to assess patients' decisions to seek care in a dental school. J. Dent. Educ. 1989, 53, 584-586. [PubMed]

47. Dolinsky, A.L. Considering the competition in strategy development: An extension of importance-performance analysis. J. Health Care Mark. 1991, 11, 31-36. [PubMed]

48. Wu, H.H.; Shieh, J.I.; Pan, W.R. Applying importance-performance analysis to analyze service quality: A case of two coach companies. J. Inf. Optim. Sci. 2008, 29, 1203-1214.

49. Shieh, J.I.; Wu, H.H. Applying importance-performance analysis to compare the changes of a convenient store. Qual. Quant. 2009, 43, 391-400. [CrossRef]

50. Wu, C.P. Using IPA Approach to Analyze the Current Situation and Future Development of Kaohsiung Port, Taiwan. Master's Dissertation, Department of Shipping Technology, National Kaohsiung Marine University, Kaohsiung, Taiwan, 2016.

51. Porter, M.E. The Competitive Advantage of Nations; Harvard Business Review: New York, NY, USA, March-April 1990. Available online: http://tsakunov.com/lectures/Michael-Porter-The-CompetitiveAdvantage-of-Nations-cover-story.pdf (accessed on 5 June 2017).

52. International Institute for Management Development (IMD). World Competitiveness Yearbook; International Institute for Management Development: Lausanne, Switzerland, 2014.

53. Ihlanfeldt, K.R. The importance of the central city to the regional and national economy: A review of the arguments and empirical evidence. Cityscape A J. Policy Dev. Res. 1995, 1, 125-150.

54. Kim, C. A Model Development for Measuring Global Competitiveness of the Tourism Industry in the Asia-Pacific Region; Korea Institute for International Economic Policy: Seoul, Korea, 2000.

55. Lever, W. F.; Turok, I. Competitive Cities: Introduction to the Review. Urban Stud. 1999, 36, 791-793. [CrossRef]

56. Begg, I. Cities and Competitiveness. Urban Stud. 1999, 36, 795-809. [CrossRef]

57. Kresl, P.K. Competitiveness and the Urban Economy: Twenty-Four Large us Metropolitan Areas. Urban Stud. 1999, 36, 1017-1027. [CrossRef]

58. Kresl, P.K. The Determinants of Urban Competitiveness. In North American Cities and the Global Economy: Challenges and Opportunities; Kresl, P., Gappert, G., Eds.; Sage Publications: London, UK, 1995; pp. 45-68.

59. Crouch, G.; Ritchie, J. Tourism, competitiveness, and social prosperity. J. Bus. Res. 1999, 44, $137-152$. [CrossRef]

60. Asia-Pacific Cultural creative industry Association. Cultural Creative Industry Revitalizing: Year 2013; Business Weekly Group: Taipei, Taiwan, 2013.

61. Florida, R.; Tinagli, I. Europe in the Creative Age; Carnegie Mellon Software Industry Publishing: London, UK, 2004.

62. Wu, J.Y.; Chiang, Y.J. The Development and Analysis on Natural Disaster Statistics Index System in Taiwan. J. Geogr. Sci. 2008, 51, 65-84.

63. Ho, M.C.; Wu, J.Y. The Establishment of the Hotspot Evaluation System for Urban Disasters under Climate Change; Architecture and Building Research Institute, Ministry of the Interior: New Taipei City, Taiwan, 2009. 